\title{
Evaluation of NSAIDs in Acute Odontogenic Pain: A Quadriblind Study
}

\author{
Karthik R Mohan ${ }^{1}$, Mohan Narayanan², Pethagounder Thangavel Ravikumar ${ }^{3}$, Saramma M Fenn ${ }^{4}$, Sabitha Gokulraj ${ }^{5}$, Amirthaleka ${ }^{6}$
}

\begin{abstract}
Odontogenic pain refers to pain arising from the teeth or their supporting structures, the oral mucous membrane, the maxilla or mandible, or periodontal ligament membrane. Management of odontogenic pain becomes challenging in the modern era to the clinician due to its diversified etiologies.

Aim: The primary aim is to evaluate the efficacy of NSAIDs in treating acute odontogenic pain due to acute pulpitis, acute periapical abscess, and acute pain after root canal therapy.

Materials and methods: Patients visiting the outpatient department, Vinayaka Missions Sankarachariyar Dental College, Vinayaka Missions Research Foundation, with odontogenic pain due to acute pulpitis and acute periapical abscess were randomly selected. A total of 80 patients were considered and divided into 4 groups ( $n=20$ were prescribed paracetamol, $n=20$ were prescribed ibuprofen, $n=20$ were prescribed aceclofenac, $n=20$ were prescribed ketorolac). The patients in each group were not aware of the analgesic drug prescribed. (quadriblind drug trial). Pain was analyzed by the visual analog score (VAS) graded from 0 to 10, and the VAS scores were recorded at initial, 30-minutes, 1-hour, and 2-hours intervals.

Result: Ketorolac is better in relieving the odontogenic pain when compared to paracetamol, ibuprofen, and aceclofenac.

Conclusion: Ketorolac is an effective NSAID in relieving the odontogenic pain.

Clinical significance: This study helps to evaluate the effectiveness of nonsteroidal anti-inflammatory drugs for odontogenic pain and helps in identifying the more potent NSAID for odontogenic pain without the use of inferior alveolar nerve block.

Keywords: Analgesics, Irreversible pulpitis, Odontogenic pain.

World Journal of Dentistry (2019): 10.5005/jp-journals-10015-1649
\end{abstract}

\section{INTRODUCTION}

Pain is an unpleasant noxious stimuli associated with actual or potential tissue damage or associated in terms of such damage. Odontogenic pain refers to pain initiating from the teeth or their supporting structures-the oral mucous membrane, gingiva, maxilla, mandible, and periodontal ligament. ${ }^{1}$ Insult of the tooth due to dental caries causes the bacterial products to infiltrate the underlying pulp via the dentinal tubules. Or trauma resulting in exposed pulp or dental restoration such as polyacrylic acid that leaches from a glass ionomer restoration or acid etching with $37 \%$ phosphoric acid prior to application of composite restoration that are closer to the dental pulp results in pulpal inflammation (pulpitis). If such tooth affected by pulpitis are neglected from root canal treatment procedure, that leads to chronic irreversible pulpitis; if further neglected, such tooth becomes infected with periapical abscess due to the spread of microorganisms through the apical foramen of the affected root into the underlying supportive structure, maxilla and mandible or can cause inflammation of the apical periodontal ligament fibers (apical periodontitis). Dental pain is the most common reason for a patient to seek dentist for treatment. A variety of NSAIDS are used in dentistry today. The primary aim and objective is to evaluate the efficacy of NSAIDS paracetamol, ibuprofen, aceclofenac, ketorolac in acute odontogenic pain due to acute pulpitis, acute periapical abscess, and pain after endodontic treatment.

\section{Materials and Methods}

Patients visiting the outpatient department, Vinayaka Missions Sankarachariyar Dental College, Vinayaka Missions Research

\begin{abstract}
${ }^{1-6}$ Department of Oral Medicine and Radiology, Vinayaka Missions Research Foundation (Deemed to be University), Vinayaka Missions Sankarachariyar Dental College, Salem, Tamil Nadu, India

Corresponding Author: Karthik R Mohan, Department of Oral Medicine and Radiology, Vinayaka Missions Research Foundation (Deemed to be University), Vinayaka Missions Sankarachariyar Dental College, Salem, Tamil Nadu, India, Phone: +91 8870659334, e-mail: drkarthik@vmsdc.edu.in

How to cite this article: Mohan KR, Narayanan M, Ravikumar PT, et al. Evaluation of NSAIDs in Acute Odontogenic Pain: A Quadriblind Study. World J Dent 2019;10(5):384-389.

Source of support: Nil

Conflict of interest: None
\end{abstract}

Foundation, with odontogenic pain due to acute pulpitis and acute periapical abscess were randomly selected. A total of 80 patients were considered and divided into 4 groups ( $n=20$ were prescribed paracetamol, $n=20$ were prescribed ibuprofen, $n=20$ were prescribed aceclofenac, $n=20$ were prescribed ketorolac). The patients in each group were not aware of the analgesic drug prescribed (quadriblind drug trial). The pain was analyzed by the visual analog score (VAS) graded from 0 to 10, and the VAS scores were recorded at initial, 30-minutes, 1-hour, and 2-hours intervals.

\section{Inclusion Criteria}

Patients aged $>15$ but less than 40 years with acute odontogenic pain due to acute pulpitis, acute exacerbation of chronic irreversible 
pulpitis and acute periapical abscess, and patients revisiting outpatient department for odontogenic pain after root canal therapy.

\section{Exclusion Criteria}

Patients aged $>40$ years and less than 15 years, patients with known history of drug allergy to NSAIDS, patients who were not willing to participate or give an informed consent for the study, patients with known history of renal or hepatic disorders, patients who were pregnant, patients who were diabetic, patients who were bedridden or terminally ill, and patients with oral cancers.

\section{Results}

Among the total $(N=80)$ population, study groups were divided into 4 groups comprising 20 per group ( $n=20$ for paracetamol, $n=$ 20 for ibuprofen, $n=20$ for aceclofenac, $n=20$ for ketorolac). The mean age group of the population was 30 years. Among the total 80 study population, $57 \%$ were males and $43 \%$ were females (Fig. 1).

About $33.8 \%$ of the population were diagnosed with acute pulpitis, $13.8 \%$ were diagnosed with acute exacerbation of chronic irreversible pulpitis, $21.3 \%$ were diagnosed with acute periapical abscess, and $31.3 \%$ were diagnosed with pain after root canal treatment procedures (Fig. 2).

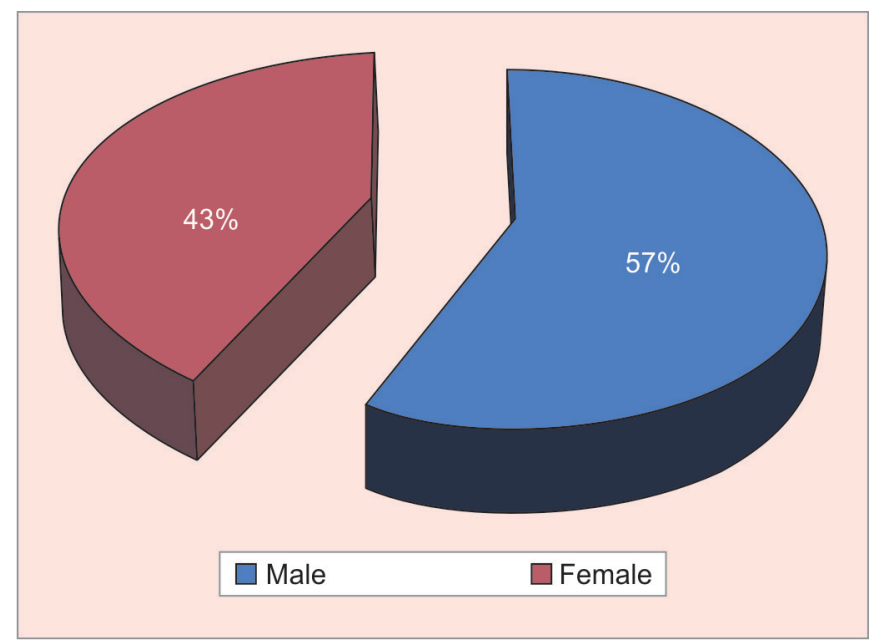

Fig. 1: Distribution of gender among the study groups

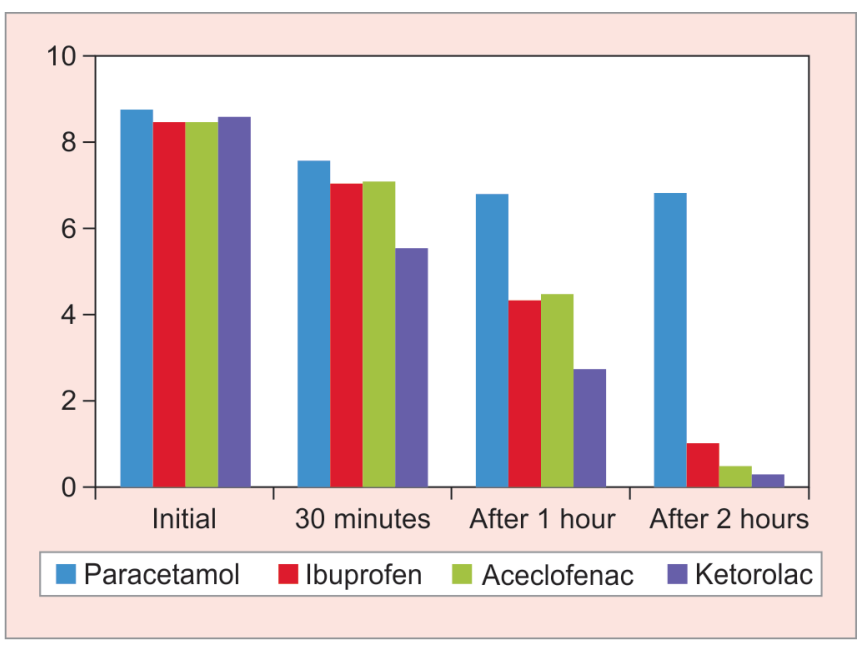

Fig. 3: Comparison of NSAIDs based on VAS scores
The comparison of the various NSAIDs drug group with VAS scores is depicted in Figure 3.

The overall effectiveness of the NSAIDs in each conditions of odontogenic pain is depicted in Figure 4.

The logistic regression curve clearly depicts that all the NSAIDS included in the study population reduced the VAS score and hence useful in relieving the odontogenic pain (Fig. 5).

The various research studies of NSAIDS in odontogenic pain was summarized in Table 1.

To find the significant difference in the multivariate analysis, the Kruskal-Wallis test was used and for repeated measures in VAS (visual analog scores), the Friedman test was used, and the probability value 0.0005 is considered as statistically significant level between the study groups.

The Kruskal-Wallis test showed a statistically significant $p$ value of 0.0005 for ibuprofen, aceclofenac, and ketorolac group except for paracetamol group with a $p$ value of 0.119 , which is not statistically significant (Table 2).

The Friedman test showed a statistically significant $p$ value of 0.0005 and the Chi-square values for paracetamol, ibuprofen, aceclofenac, and ketorolac group (Table 3 ).

Ibuprofen $(600 \mathrm{mg})$ is more effective in treating postoperative odontogenic pain after root canal therapy. In endodontic pain

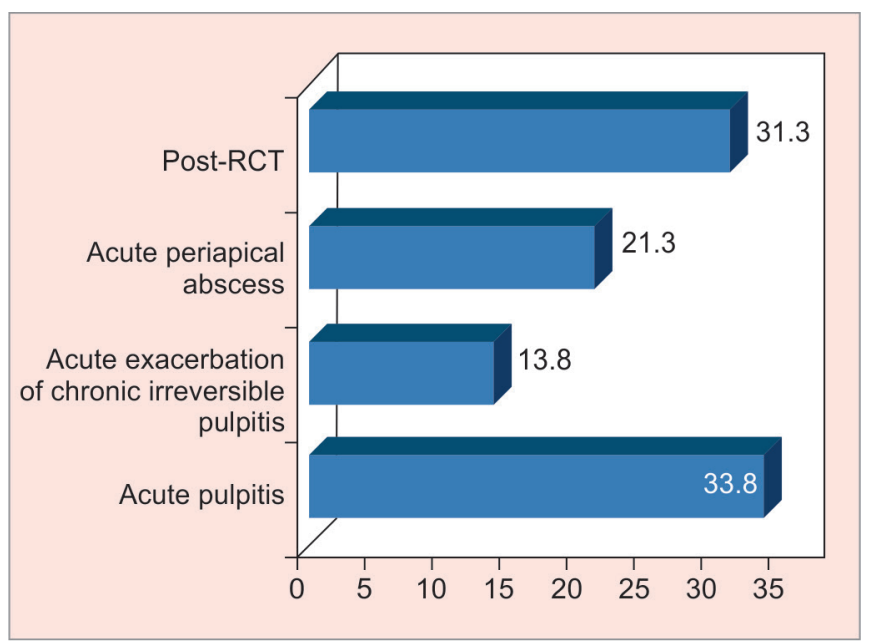

Fig. 2: Distribution of diagnosis made among the study population with odontogenic pain

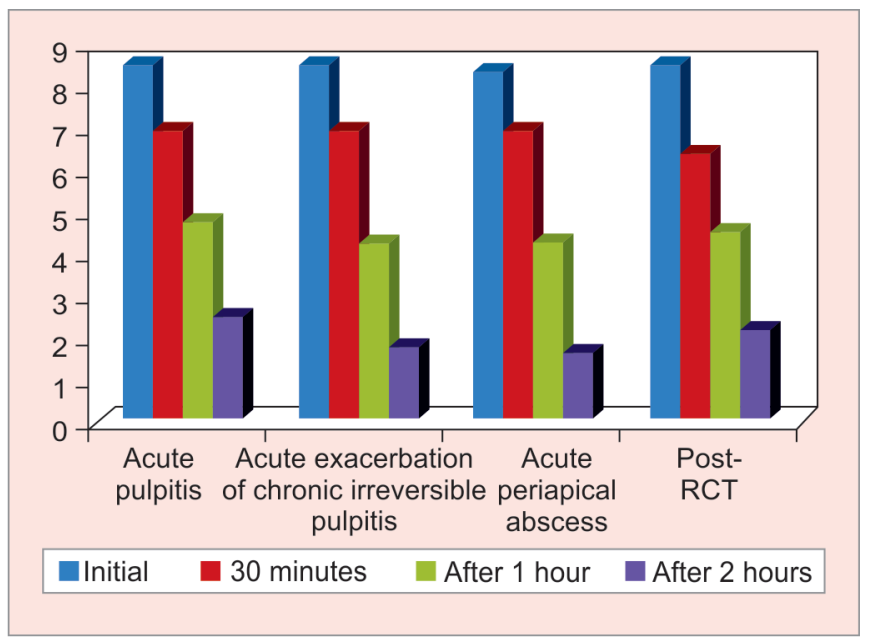

Fig. 4: Distribution of VAS scores among various NSAIDs 


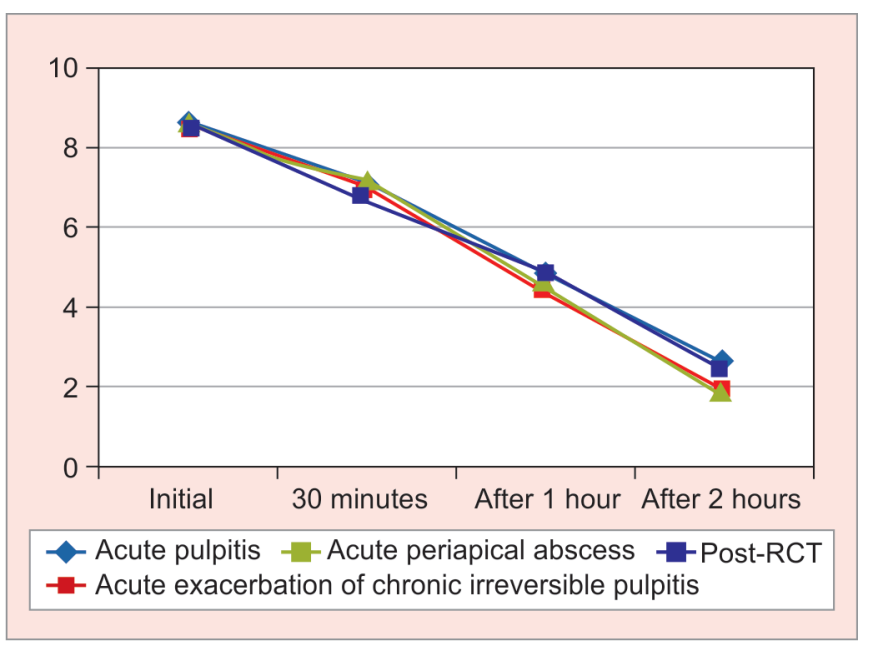

Fig. 5: Logistic regression curve based on VAS scores

patients, a single dose of ibuprofen sodium dihydrate provides faster onset of pain relief and a greater reduction in spontaneous and evoked pain compared with ibuprofen acid. The Friedman test result for ibuprofen, aceclofenac, and ketorolac group showed a statistically significant value of 0.005 . This shows that ibuprofen, aceclofenac, and ketorolac has a better efficacy in odontogenic pain due to acute pulpitis, acute exacerbation of chronic irreversible pulpitis, acute periapical abscess, and pain after root canal therapy than paracetamol, which is mainly concerned for its antipyretic action than analgesic action.

\section{Discussion}

\section{Brief History of NSAIDS}

The analgesic and antipyretic action started from the use of willow bark (Salix alba), salicylic acid obtained by hydrolysis of the bitter glycoside obtained from this plant. Sodium salicylate was used for fever and pain in 1875. The nonsteroidal anti-inflammatory drugs act by peripheral pain mechanisms by the inhibition of prostaglandin synthesis that is released from diseased pulp tissue, but some also act in central nervous system (CNS) to raise pain threshold. ${ }^{4}$

Joseph von Mering was the first person who used paracetamol (acetaminophen) in Humans in 1893. Paracetamol is used for mildto-moderate dental pain. Paracetamol belongs to aniline analgesics and is the active metabolite of phenacetin and acetanilide. Paracetamol has poor ability to inhibit COX in the presence of high concentrations of peroxides, as are found at sites of inflammation. The pharmacological properties have been reviewed by Brune. ${ }^{5}$ Oral paracetamol has excellent bioavailability. Peak plasma concentration of paracetamol taken orally occurs within 30-60 minutes and its half-life is about 2 hours. A small proportion of paracetamol undergoes CYP-mediated $N$-hydroxylation to form $N$-acetyl- $p$-benzoquinoneimine (NAPQI), a highly reactive intermediate. This metabolite normally reacts with sulfhydryl groups in glutathione (GSH) and is thereby rendered harmless. The antipyretic effect of paracetamol is reviewed by Ouellet and Percival, and Boutaud et al. 6,7

Paracetamol is particularly useful when NSAIDS are contraindicated due to hypersensitivity or history of gastrointestinal ulceration or bleeding. Paracetamol is hepatotoxic and nephrotoxic in high doses.
Aceclofenac, a highly selective cox-2 inhibitor, was approved for medical use in 1992, NSAID of phenyl acetic acid group. It belongs to class II biopharmaceutical classification system (BCS) based on its solubility and permeability. Aceclofenac is insoluble in water but gets conjugated in the human hepatocytes and gets metabolized to a major metabolite 4-hydroxy aceclofenac. The mean plasma half-life of aceclofenac is 4-4.3 hours. Aceclofenac acts as a potent anti-inflammatory drug by decreasing the expression or synthesis of mediators of inflammation including interleukin (IL-1 $\beta$ ), tumor necrosis factor (TNF), cell adhesion molecules from neutrophils, selectively inhibits cox- 2 enzyme, and prevents the formation of PGE2. Aceclofenac acts by inhibition of cyclooxygenase that is involved in prostaglandins production that results in pain. Aceclofenac does not inhibit gastro-duodenal blood flow; hence, the ulcerogenic potential of gastric mucosal lining of stomach by aceclofenac is considerably lesser than ibuprofen, hence preferred by clinicians in the treatment of odontogenic pain when compared to ibuprofen. The oral dose of aceclofenac for the treatment of odontogenic pain is $100 \mathrm{mg}$ twice daily. Aceclofenac must not be prescribed for treating odontogenic pain in pregnant patients as it may cause patent ductus arteriosus in neonates.

Acelofenac has better gastric tolerance than other NSAIDS. Aceclofenac is a novel NSAID that exerts chondroprotective action by stimulating glycosaminoglycans, the main extracellular cartilage matrix macromolecule. Aceclofenac significantly diminished the L-selectin-dependent neutrophil adhesion to endothelial cells. ${ }^{8}$

Ibuprofen was discovered by Dr Stewart Adams and his colleagues in the United Kingdom in the 1950s. Ibuprofen belongs to propionic acid derivative discovered by British Boots company during 1960s. Ibuprofen is absorbed rapidly, bound avidly to protein, and undergoes hepatic metabolism $(90 \%$ is metabolized to hydroxylate or carboxylate derivatives. The half-life of ibuprofen is around 2 hours. ${ }^{9}$

Ketorolac was developed in 1989 by Syntex Corp. Ketorolac is a potent analgesic but only a moderately effective antiinflammatory drug. Ketorolac has a greater systemic analgesic than anti-inflammatory activity. It inhibits platelet aggregation and promotes gastric ulceration. The pharmacology of ketorolac has been reviewed by Buckley and Brogden. ${ }^{10}$

Ketorolac has a rapid onset of action, extensive protein binding, and a short duration of action oral bioavailability is $80 \%$. Urinary excretion accounts for $90 \%$ of eliminated drug, with about $10 \%$ excreted unchanged and the remainder as a glucorinated conjugate. Ketorolac (administered orally (10 mg twice daily) as a tromethamine salt used as a short-term alternative to opioids for about 5 days for the treatment of moderate to severe pain. Unlike opiods tolerance, withdrawal and respiratory depression do not occur. The common side effects of ketorolac include nausea, dizziness, headache, gastrointestinal pain, and somnolence.

Studies by Aggarwal et al., Jena et al., and Yadav et al. have shown the efficacy of oral premedication with ketorolac in anesthetic efficacy of inferior alveolar nerve block in patients with chronic irreversible pulpitis whereas our study shown the analgesic efficacy of ketorolac in patients with chronic irreversible pulpitis without inferior alveolar nerve block.

Studies conducted by Pulikkotil and Nagendrababu et al. have shown the efficacy of ibuprofen in improving the anesthetic efficacy of inferior alveolar nerve block in patients with chronic irreversible pulpitis. 
Table 1: The various research studies of NSAIDs on odontogenic pain

\begin{tabular}{|c|c|c|c|c|c|}
\hline NSAIDs & Year of study & Researchers & Sample size & Criteria & Results \\
\hline \multirow[t]{2}{*}{ Acetaminophen } & 2007 & laniro et al. ${ }^{11}$ & 40 & Irreversible pulpitis & $\begin{array}{l}71.4 \% \text { success rate for } \\
\text { acetaminophen }\end{array}$ \\
\hline & 2012 & Ramachandran et al. ${ }^{12}$ & 30 out of 120 patients & Irreversible pulpitis & $\begin{array}{l}73.3 \% \text { success rate for } \\
\text { acetaminophen }\end{array}$ \\
\hline \multirow[t]{2}{*}{ Aceclofenac } & 2010 & Moore et al. ${ }^{13}$ & 217 & Postoperative pain & $\begin{array}{l}\text { Aceclofenac could not be } \\
\text { distinguished from placebo }\end{array}$ \\
\hline & 2012 & Ramachandran et al. ${ }^{12}$ & 30 out of 120 patients & Irreversible pulpitis & $\begin{array}{l}90 \% \text { success rate for } \\
\text { aceclofenac }\end{array}$ \\
\hline \multirow[t]{8}{*}{ Ketorolac } & 1999 & Sadeghein et al. ${ }^{14}$ & $\begin{array}{l}33 \text { out of } 66 \text { with severe } \\
\text { pain with VAS score } \\
\text { above } 7\end{array}$ & $\begin{array}{l}\text { Acute apical } \\
\text { periodontitis }\end{array}$ & $\begin{array}{l}\text { Ketorolac significantly reduced } \\
\text { pain than acetaminophen } \\
(p=0.05)\end{array}$ \\
\hline & 2000 & Bezrukova et al. ${ }^{15}$ & 50 & $\begin{array}{l}\text { Pulpitis and } \\
\text { periodontitis }\end{array}$ & $\begin{array}{l}\text { Ketanov showed effectiveness } \\
\text { and no side effects }\end{array}$ \\
\hline & 2010 & Aggarwal et al. ${ }^{16}$ & $\begin{array}{l}24 \text { out of } 62 \text { patients } \\
\text { prescribed } 10 \mathrm{mg} \\
\text { ketorolac }\end{array}$ & Irreversible pulpitis & $\begin{array}{l}\text { Premedication gave } 32 \% \\
\text { success rate }\end{array}$ \\
\hline & 2013 & Jena et al. ${ }^{17}$ & 100 & Irreversible pulpitis & $\begin{array}{l}70 \% \text { success rate for ketorolac } \\
\text { group }\end{array}$ \\
\hline & 2015 & Yadav et al. ${ }^{18}$ & $\begin{array}{l}25 \text { out of } 50 \text { patients } \\
\text { prescribed } 10 \mathrm{mg} \\
\text { ketorolac }\end{array}$ & Irreversible pulpitis & $\begin{array}{l}76 \% \text { success rate for ketorolac } \\
\text { premedication }\end{array}$ \\
\hline & 2016 & Ganguly et al. ${ }^{19}$ & 150 & Irreversible pulpitis & $\begin{array}{l}\text { Ketorolac was not as effective } \\
\text { in endodontic pain relief when } \\
\text { compared to dexamethasone }\end{array}$ \\
\hline & 2017 & Vieyra et al. ${ }^{20}$ & 18 out of 54 & $\begin{array}{l}\text { Postoperative pain in } \\
\text { teeth with irreversible } \\
\text { pulpitis and apical } \\
\text { periodontitis and }\end{array}$ & $\begin{array}{l}\text { Ketorolac was as effective } \\
\text { for relief of postoperative } \\
\text { endodontic pain }\end{array}$ \\
\hline & 2018 & $\begin{array}{l}\text { Gowri Sivaram- } \\
\text { akrishnan, Kannan } \\
\text { Sridharan }^{21}\end{array}$ & 221 patients & Irreversible pulpitis & $\begin{array}{l}\text { Oral ketorolac is effective for } \\
\text { pain relief for treatment of } \\
\text { irreversible pulpitis }\end{array}$ \\
\hline \multirow[t]{2}{*}{ Ibuprofen } & 2004 & Menhinick et al. ${ }^{23}$ & 57 & $\begin{array}{l}\text { Postoperative } \\
\text { endodontic pain }\end{array}$ & $\begin{array}{l}\text { Combination of ibuprofen with } \\
\text { acetaminophen (paracetamol) } \\
\text { is better than ibuprofen alone } \\
\text { in patients with postoperative } \\
\text { endodontic pain }\end{array}$ \\
\hline & 2019 & de Geus JL et al. ${ }^{22}$ & & & $\begin{array}{l}\text { Ibuprofen is beneficial as a } \\
\text { premedication in success of } \\
\text { inferior alveolar nerve block in } \\
\text { irreversible pulpitis }\end{array}$ \\
\hline \multirow[t]{2}{*}{ Ibuprofen $600 \mathrm{mg}$} & 2010 & Parirokh et al. ${ }^{24}$ & 50 & Irreversible pulpitis & $\begin{array}{l}\text { Increased success rate of pain } \\
\text { relief }\end{array}$ \\
\hline & 2012 & $\begin{array}{l}\text { Pozzi et al., } \\
\text { Ramachandran et al. }{ }^{25}\end{array}$ & $N=30$ & Irreversible pulpitis & $\begin{array}{l}400 \mathrm{mg} \text { ibuprofen provides } \\
\text { longer relief } 93.3 \% \text { success rate } \\
\text { for irreversible pulpitis }\end{array}$ \\
\hline \multirow[t]{2}{*}{ Ibuprofen 400 mg } & 2013 & Shahi et al. ${ }^{26}$ & 55 out of 165 & Irreversible pulpitis & $\begin{array}{l}\text { No significant difference in pain } \\
\text { relief }\end{array}$ \\
\hline & 2017 & Smith et al. ${ }^{27}$ & & $\begin{array}{l}\text { Postoperative } \\
\text { endodontic pain }\end{array}$ & $\begin{array}{l}\text { Ibuprofen showed } \\
\text { effectiveness in tooth pain }\end{array}$ \\
\hline \multirow[t]{2}{*}{ Ibuprofen 400 mg } & 2018 & Pulikkotil et al. ${ }^{28}$ & $N=1654$ & Irreversible pulpitis & $\begin{array}{l}400 \text { mg ibuprofen has good suc- } \\
\text { cess rate in irreversible pulpitis }\end{array}$ \\
\hline & 2018 & Nagendrababu et al. ${ }^{29}$ & $N=1034$ & Irreversible pulpitis & $\begin{array}{l}\text { Dose-dependent } \\
\text { ibuprofen }>400 \mathrm{mg} / \text { day } \\
\text { was shown to be effective }\end{array}$ \\
\hline
\end{tabular}

Our study correlated with the findings of Curtis et al., who stated that ketorolac effectively reduces severe odontogenic pain within 40 minutes after administration in human subjects, with minimal side effects. ${ }^{2}$ Our study correlated with the study by Praveen et al. who stated that ketorolac showed effective reduction in pain scales when compared with other NSAIDS. ${ }^{3}$ 
Table 2: Kruskal-Wallis test among various NSAIDs

\begin{tabular}{llllllll}
\hline & & \multicolumn{3}{c}{ Mean rank } & \multicolumn{2}{c}{$\begin{array}{c}\text { Chi-square } \\
\text { values }\end{array}$} & $p$ values \\
\cline { 3 - 7 } Analgesic prescribed & $N$ & VAS (initial) & VAS (30 minutes) & VAS (1 hour) & VAS (2 hours) & 5.858 & 0.119 \\
\hline Paracetamol & 20 & 49.00 & 54.80 & 68.10 & 70.50 & 21.382 & 0.0005 \\
Ibuprofen & 20 & 35.00 & 39.95 & 37.75 & 41.10 & 52.495 & 0.0005 \\
Aceclofenac & 20 & 37.00 & 43.18 & 40.05 & 28.00 & 56.51 & 0.0005 \\
Ketorolac & 20 & 41.00 & 24.08 & 16.10 & 22.40 & &
\end{tabular}

Table 3: Friedman test among various NSAIDs

\begin{tabular}{|c|c|c|c|c|c|c|c|}
\hline \multirow[b]{2}{*}{ Analgesic prescribed } & \multirow[b]{2}{*}{$N$} & \multicolumn{4}{|c|}{ Mean rank } & \multirow[b]{2}{*}{$\begin{array}{l}\text { Chi-square } \\
\text { values }\end{array}$} & \multirow[b]{2}{*}{$p$ values } \\
\hline & & VAS (initial) & VAS $(30 \mathrm{~mm})$ & VAS (1 hour) & $\begin{array}{l}\text { VAS (2 } \\
\text { hours) }\end{array}$ & & \\
\hline Paracetamol & 20 & 3.98 & 2.73 & 1.68 & 1.63 & 49.79 & 0.0005 \\
\hline Ibuprofen & 20 & 3.98 & 3.03 & 2.00 & 1.00 & 59.71 & 0.0005 \\
\hline Aceclofenac & 20 & 4.00 & 3.00 & 2.00 & 1.00 & 60.00 & 0.0005 \\
\hline Ketorolac & 20 & 4.00 & 2.98 & 2.03 & 1.00 & 59.71 & 0.0005 \\
\hline
\end{tabular}

Sivaramakrishnan et al. concluded in their study that oral ketorolac can be successfully administered as a premedication before conventional inferior alveolar nerve block for endodontic treatment for irreversible pulpitis. ${ }^{19}$

Our study also correlated with Vieyra et al. who concluded that oral ketorolac was as safe and effective for postoperative pain relief in patients with symptomatic apical periodontitis. ${ }^{20}$

Our study is contradictory to the study by de Geus et al. who concluded that ibuprofen premedication is beneficial for the success of inferior alveolar nerve block in patients with irreversible pulpitis. $^{22}$

\section{LIMITATIONS}

The limitation in our study is that our study does not evaluate the efficacy of NSAIDs in other causes of odontogenic pain such as acute pericoronitis, acute pericoronal abscess, and oral cancer. Our study also does not evaluate the analgesic efficacy in medically compromised patients such as uncontrolled diabetes, patients with known renal or hepatic disorders and in pregnant patients.

\section{Conclusion}

Among the NSAIDs, ketorolac has more potent analgesic efficacy in the treatment of odontogenic pain when compared to other NSAIDS.

\section{Declarations}

\section{Ethical Approval and Consent to Participate}

Ethical approval was obtained from the Institutional Ethics Committee-Vinayaka Missions Sankarachariyar Dental College, Vinayaka Missions Research Foundation.

\section{Consent for Publication}

Written informed consent was obtained from the participants for the publication of their individual details and accompanying images in this manuscript.

\section{Authors Contributions}

Karthik R Mohan contributed in drafting. Mohan Narayanan participated in idea. Ravikumar PT participated in material collection. Saramma M Fenn participated in statistical analysis.
Sabitha Gokulraj conceived and Amirthaleka participated in designing and its coordination. All authors read and approved the final manuscript.

\section{ACKnOWLedgments}

Arunadevi J BDS and department faculties of oral medicine, diagnosis, and radiology, Vinayaka Missions Research Foundation, Vinayaka Missions Sankarachariyar Dental College, Salem, Tamil Nadu India.

\section{References}

1. Renton T. Dental (Odontogenic) Pain. Rev Pain 2011;5(1):2-7. DOI: 10.1177/204946371100500102.

2. Curtis $P, G a r t m a n L A$, Green DB. Utilization of ketorolac tromethamine for control of severe odontogenic pain. J Endod 1994;20(9):457-459. DOI: 10.1016/S0099-2399(06)80038-5.

3. Praveen R, Thakur S, Kirthiga M. Comparative Evaluation of Premedication with Ketorolac and Prednisolone on Postendodontic Pain: A Double-blind Randomized Controlled Trial. J Endod 2017;43(5):667-673. DOI: 10.1016/j.joen.2016.12.012.

4. Rainsford KD. Anti-inflammatory drugs in the 21st century. Subcell Biochem 2007;42:3-27.

5. Brune K. The Pharmacological profile of non-opioid (OTC) analgesics: aspirin, paracetamol (acetaminophen), ibuprofen and phenazones. Agents Actions Suppl 1988;25:9-19.

6. Boutaud $\mathrm{O}$, Aronoff DM, Ichardson $\mathrm{JH}$, et al. Determinants of the cellular specificity of acetaminophen as an inhibitor of Prostaglandin $\mathrm{H}(2)$ synthases. Proc Natl Acad Sci USA 2002;99:7130-7135. DOI: 10.1073/pnas.102588199.

7. Ouellet $M$, Percival MD. Mechanism of acetaminophen inhibition of cyclooxygenase isoforms. Arch Biochem Biophys 2001;38:7273-7380. DOI: 10.1006/abbi.2000.2232.

8. González-Alvaro I, Carmona L, Díaz-González F, et al. Aceclofenac, a new nonsteroidal antiinflammatory drug, decreases the expression and function of some adhesion molecules on human neutrophils. J Rheumatol 1996;23(4):723-729.

9. Davies NM. Clinical pharmacokinetics of ibuprofen. The first 30 years. Clin Pharmacokinet 1998a;34:101-154. DOI: 10.2165/00003088199834020-00002.

10. Buckley MM, Brodgen RN. Ketorolac. A review of its pharmacodynamic and pharmacokinetic properties and therapeutic potential. Drugs 1990;39:86-109. DOI: 10.2165/00003495-199039010-00008.

11. Ianiro SR, Jeansonne BG, McNeal SF, et al. The effect of preoperative acetaminophen or a combination of acetaminophen and Ibuprofen on the success of inferior alveolar nerve block for teeth with 
irreversible pulpitis. J Endod 2007;33(1):11-14. DOI: 10.1016/ j.joen.2006.09.005.

12. Ramachandran A, Khan SIR, Mohanavelu D, et al. The efficacy of pre-operative oral medication of paracetamol, ibuprofen, and aceclofenac on the success of maxillary infiltration anesthesia in patients with irreversible pulpitis: A double-blind, randomized controlled clinical trial. J Conserv Dent 2012;15(4):310-314. DOI: 10.4103/0972-0707.101881.

13. Moore RA, Derry S, McQuay HJ. Single dose oral aceclofenac for postoperative pain in adults. Cochrane Database Syst Rev 2009;8(3):CD007588. DOI: 10.1002/14651858.CD007588.pub2.

14. Sadehein A. A comparison of ketorolac tromethamine and acetaminophen codeine in the management of acute apical periodontitis. Journal of Endodontics [Internet] 2019 Feb;25(4): 257-259, available from: https://www.jendodon.com/article/S00992399(99)80154-X/fulltext.

15. Bezrukova IV, Gerchikov LN. The analgesic action of the preparation Ketanov in the combined treatment of patients with pulpitis and periodontitis. Stomatologiia (Mosk) 2000;79(2):10-11.

16. Aggarwal V, Singla M, Kabi D. Comparative evaluation of effect of preoperative oral medication of ibuprofen and ketorolac on anesthetic efficacy of inferior alveolar nerve block with lidocaine in patients with irreversible pulpitis: a prospective, double-blind, randomized clinical trial. J Endod 2010;36(3):375-378. DOI: 10.1016/ j.joen.2009.11.010.

17. Jena A, Shashirekha G. Effect of preoperative medications on the efficacy of inferior alveolar nerve block in patients with irreversible pulpitis: a placebo-controlled clinical study. J Conserv Dent 2013;16(2):171-174. DOI: 10.4103/0972-0707.108209.

18. Yadav M, Grewal MS, Grewal S, et al. Comparison of Preoperative Oral Ketorolac on Anesthetic Efficacy of Inferior Alveolar Nerve Block and Buccal and Lingual Infiltration with Articaine and Lidocaine in Patients with Irreversible Pulpitis: A Prospective, Randomized, Controlled, Double-blind Study. J Endod 2015;41(11):1773-1777. DOI: 10.1016/ j.joen.2015.06.008.

19. Sivaramakrishnan G, Sridharan K. Oral Ketorolac with Inferior Alveolar Nerve Block for Irreversible Pulpitis: A Systematic Review and Meta-analysis. Open Dent J 2018;12:340-346. DOI: 10.2174/1874210601812010340.

20. Vieyra JP, Acosta FO, Enriquez FJJ, et al. The Effect of Preoperative Administration of Single-Dose Ketorolac, Non-Steroidal Anti-Inflammatory
Drug and Placebo on Postoperative Pain in Teeth with Irreversible Pulpitis and Apical Periodontitis. J Dental Sci 2018;3(4):000175.

21. Gowri S, Sridharan K. Oral Ketorolac with Inferior Alveolar Nerve Block for Irreversible Pulpitis: A Systematic Review and Metaanalysis. The Open Dentistry Journal 2018;12:340-346. DOI: 10.2174/1874210601812010340.

22. de Geus JL, Wambier LM, Boing TF, et al. Effect of Ibuprofen on the efficacy of inferior alveolar nerve block in patients with irreversible pulpitis: A meta-analysis. Aust Endod J 2019;45(2):246-258. DOI: 10.1111/aej.12306.

23. Menhinick KA, Gutmann JL, Regan JD, et al. The efficacy of pain control following nonsurgical root canal treatment using ibuprofen or a combination of ibuprofen and acetaminophen in a randomized, double-blind, placebo-controlled study. Int Endod J 2004;37(8): 531-541. DOI: 10.1111/j.1365-2591.2004.00836.x.

24. Parirokh M, Ashouri R, Rekabi AR, et al. The effect of premedication with ibuprofen and indomethacin on the success of inferior alveolar nerve block for teeth with irreversible pulpitis. J Endod 2010;36(9):1450-1454. DOI: 10.1016/j.joen.2010.05.007.

25. Pozzi A, Gallelli L. Pain management for dentists: the role of ibuprofen. Ann Stomatol (Roma) 2012 Apr 15;2(3-4 Suppl):3-24.

26. Shahi S, Mokhtari H, Rahimi S, et al. Effect of premedication with ibuprofen and dexamethasone on success rate of inferior alveolar nerve block for teeth with asymptomatic irreversible pulpitis: a randomized clinical trial. J Endod 2013;39(2):160-162. DOI: 10.1016/ j.joen.2012.10.011.

27. Smith EA, Marshall JG, Selph SS, et al. Nonsteroidal Anti-inflammatory Drugs for Managing Postoperative Endodontic Pain in Patients Who Present with Preoperative Pain: A Systematic Review and Metaanalysis. J Endod 2017 Jan;43(1):7-15.

28. Pulikkotil SJ, Nagendrababu V, Veettil SK, et al. Effect of oral premedication on the anaesthetic efficacy of inferior alveolar nerve block in patients with irreversible pulpitis - A systematic review and network meta-analysis of randomized controlled trials. Int Endod J 2018;51(9):989-1004. DOI: 10.1111/iej.12912.

29. Nagendrababu V, Pulikkotil SJ, Veettil SK, et al. Effect of Nonsteroidal Anti-inflammatory Drug as an Oral Premedication on the Anesthetic Success of Inferior Alveolar Nerve Block in Treatment of Irreversible Pulpitis: A Systematic Review with Meta-analysis and Trial Sequential Analysis. J Endod 2018;44(6):914-922. DOI: 10.1016/j.joen.2018. 02.017. 